\title{
Implementation of Entrepreneurship-Based Learning Management
}

\author{
Rahmi Firdausi 1 *, Karyono Ibnu Ahmad 2, Ririanti Rachmayanie 3 \\ 1 Master Program of Early Childhood Teacher Education, Universitas Lambung Mangkurat, Banjarmasin \\ 70123 Indonesia \\ 2 Master Program of Education Management, Universitas Lambung Mangkurat, Banjarmasin 70123 \\ Indonesia \\ ${ }^{3}$ Department of Guidance and Counselling, Universitas Lambung Mangkurat, Banjarmasin 70123 \\ Indonesia
}

Article history:

Submission November 2019

Revised March 2020

Accepted March 2020

*Corresponding author:

E-mail: rahmifyrda@gmail.com

\begin{abstract}
Entrepreneurship-based learning for early childhood encompasses the teacher's effort to grow and develop entrepreneurial values, through participation in creative and fun activities. This study aims to describe in-depth: (1) learning management, (2) factors that influence entrepreneurship-based learning management in Mata Najwa Kindergarten. Furthermore, data analysis was qualitatively carried out through collection via interviews, observation, and documentation. The results showed that the 2013 curriculum was integrated with the value of entrepreneurship implementation at the center and supporting activities during planning. Also, evaluations were conducted through daily observations, midterm report cards, and final semester report cards, which serve as obstacles in learning, with there are solutions for obstacles in learning through supporting factors. Therefore, it is anticipated that the study results are taken into consideration for learning innovations in other schools.
\end{abstract}

Keywords: Entrepreneurship, learning management, implementation

\section{Introduction}

Indonesia excels in a period of 2045 prepared by the application from the map of the industrial revolution ere 4.0. answering education as a solution to the impact of the industrial era 4.0. required entrepreneur education. The concept of entrepreneurial education will create creative and innovative children who able to overcome the obstacles in the future. Moravec states that industry 4.0 requires the education to build individual innovation practices and student empowerment teams to produce innovation (Sumarmo \& Gimin, 2019). Schools are educational institutions designed for the development of human potentials. Also, the purpose of education is to improve the quality of human resources with the anticipation of producing superior and characterized human beings, raised through the affirmation of each activity that is integrated into entrepreneurship-based learning in school.

Ningrum's opinion (2017) reported entrepreneurship as a soul, attitude, ability to create something new, valuable and useful for personal consumption and others, while entrepreneurs are skilled personnel in the aspect of developing personal businesses and taking advantage of opportunities, to improve their lives. Moreover, Nurseto (2010) established that efforts needed to instill the required entrepreneurship for teachers ought not to be limited to master the concepts, but also have the ability to perform the related

How to cite:

Firdausi, R., Ahmad, K, I., \& Rachmayanie, R. (2019). Implementation of entrepreneurship- based learning management. Journal of K6, Education, and Management, 2 (3), 174 - 185. doi:10.11594/jk6em.02.03.01 
activities. These include the application of all existing conceptions.

The act of fostering this character in children is initiated with its inculcation in the teacher, which serves as the main key, as outlined in the learning activities at school. The school tends to provide support in creating the idea of entrepreneurship for children through programs that are possible through the curriculum or student activities. Meanwhile, the success of this program is however known through the criteria achievement by students, teachers, and principals. Moreover, the effort made by conducting a variety of fun activities in learning further assists all aspects of child development. This is because learning is meant to be active, creative, effective and fun.

Nurhafizah (2018) stated the requirement entrepreneurship education is applied to the curriculum by identifying the types of activities in school that lead to the potential accomplishment in daily life, encompassing: (1) It is integrated into all learning activities through play. This is an important value, which demands the formation of entrepreneurial character and supporting habits in children's behavior. Also, the characteristic is possibly attained during the learning process, through learning methods and assessment systems; and (2) The integration of entrepreneurial values within learning tools.

This application adopted to build entrepreneurial values following the characteristics and principles of child development. Fadlillah and Lilif (2013) explained that several concepts, encompassing: (1) Independent; (2) Creative; (3) Dare to take risks; (4) Action-oriented; (5) Leadership; (6) Hard Work; (7) Honesty; (8) Discipline; (9) Innovative. There is a cycle in entrepreneurship education as stated by Ciputra (Wijaya, 2017), thus, they introduce in 5 phases, which include:

a. Exploration; This phase is characterized by promoting the ability of students to search deeply for possible information through research activities and also observing surrounding opportunities.

b. Planning; students devote ideas by making plans in work side systems, by paying attention to the results of exploration.

c. Production; students are tasked with their innovation capabilities by making discoveries, developing and creating items with all the affiliated risks.

d. Communication (marketing) is characterized by socialization attempts to attract the interest of prospective customers towards the products.

e. Reflection; students at this stage tend to be evaluated from the inception of all activities with the results obtained.

Early childhood learning is a process aimed at children aged $0-6$ or $0-8$ years to promote the ability to optimally gain knowledge. Furthermore, it is expected that changes in behavior during early childhood is more effective (Fadillah, 2014). Meanwhile, learning management in this period is possibly implemented in an integrated and thematic manner with educational activities.

Entrepreneurship education is a discipline knowledge is the ability to create something new and different (Prawirokusumo, 2010). The education of entrepreneurship for early childhood through an introductory phase. Building the characters of entrepreneurship through building the traits and independent character, responsibility both theoretically, practically, concrete examples for mental establishment need time and long process (Siwiyanti, 2016). Entrepreneurship for young children is a systematic knowledge that embodies the ability to think creatively and behave innovatively. Therefore, preparation steps require the promotion of businesses that are following the development needed. Teaching the value of entrepreneurship in early childhood demands the need for the proper management of learning, which according to Novitawati (2016), includes; planning, organizing and implementing learning, as well as its evaluation. This was in line with the research by Ita (2018), who conducted the management research in Rutosoro Kindergarten, encompassing the aspects of planning, implementation, and evaluation. Based on the description above, the purpose of this study is to identify and describe: planning, implementation, and evaluation. This also in- 
volves illustrating the factors influence the implementation of entrepreneurship-based learning at Mata Najwa Kindergarten.

\section{Methodology}

The location used for this research is the Mata Najwa Kindergarten, Banjarbaru City. The research type is a case study, with research subjects being the principals, teachers, students, and parents at Mata Najwa Kindergarten, while the object is the entrepreneurship-based learning process. Therefore, the criteria used as the sampling technique was purposive, and the research design is educational ethnography, which refers to part or all of the educational process at the research site.

The research procedure was conducted in steps, which include: initial observation, identification of problems in the field, preparation of theoretical studies, data collection, processing, and presentation. Furthermore, the sources for information include the school principals, teachers, students, and parents, as well as the institutions' archives, entrepreneurship-based learning processes, field notes, and photos. Data collection is performed by several techniques, using observation guides, properly structured and in-depth interviews, as well as pictorial documentation. Subsequently, analytical techniques were performed using an interactive analysis model for data collection, reduction, and presentation, and also conclusion drawing. Also, the validation required the use of credibility and data triangulation techniques.

\section{Results and Discussion \\ Planning of entrepreneurship - based learn- ing}

Planning in entrepreneurship-based learning is initiated with the preparation of teachers, for them to possess the nature and behavior of entrepreneurs. This character value inculcation is one of the bases for vision, mission and goal formation include in the curriculum used in learning. The Findings, plans were made in TK Mata Najwa, using the 2013 curriculum was used, based on the fact that it was integrated with the value for formulating entrepreneurs that are independent, creative, honest, disciplined, hard work, leadership, results-oriented, and they dare to take action. This, according to Musfah (2012) is a type of curriculum that involves the integration of some positive values (characters), with the desire and aim to "answer" the problem with some subjects. Therefore, the incorporation of planning at Mata Najwa Kindergarten with entrepreneurial values is expected to enhance children's academic and non-academic abilities.

Yan (2018) also reported regarding the construction of the entrepreneurship curriculum in preschools, stating the need to conduct the following proportion of practical courses in the syllabus, encompassing children game and design, art, sport, music, courseware making, and education, as well as curriculum development and the environment in kindergarten. Entrepreneur value at Mata Najwa Kindergarten, also, based on the value of entrepreneurship in Islam, its characteristics according to Buchari in Anwar (2014) encompasses: (a) The nature of piety, trust, remembrance, and gratitude, (b) Honesty, (c) Wake up at dawn and work, (d) Tolerance and (e) Alms and giving.

Furthermore, the efforts of schools in preparing teachers towards improving the quality of learning were following the opinion of Asniwati (2015) which stipulated the enhanced propensity for school quality to improve when teachers have high academic skills, several years of teaching experience, impart according to the respective fields of training, and are involved in high-quality induction programs as well as professional development. This was in line with the results of Yan's research (2018) in China, which reported that strengthening the practicality of pre-school education requires the active selection of a group of teachers with strong entrepreneurial experience.

This is often expanded in early childhood education, with the inclusion of vision, mission and organizational functions, institutional goals, strategies towards their achievement, and others. The learning planning process for 
schools is standardized and known to consist of the creation of annual, semester, and monthly programs, as well as weekly and daily learning implementation plans. Moreover, proper planning has been conducted, one of which is the scheduling of programs and learning tools for each school year.

However, planning is concerned with determining the goals or objectives to be achieved, as well as the paths and resources needed to effectively and efficiently achieve the set goals. This is, therefore, an absolute requirement for every management activity, as neglecting this step leads to difficulty in the implementation of an activity, and sometimes fail to achieve the desired goals.

Proper planning at the commencement of the semester enhances the ease of coordinate the components of the learning program. This includes the formulation of methods and supporting media, determining supporting activities, and preparing the assessment methods used.

The planning stages performed at Mata Najwa Kindergarten through a planning stage prepared by the Department of Education, principals, leaders of foundations, teacher guardians of students, and school residents (Delitasari \& Hidayah, 2017). Planning an entrepreneurship education program involves the formulation of its objectives, vision, and mission. The agreement reached was, therefore, evaluated, and all stakeholders served as executors of the program.

The plans towards learning conducted at Mata Najwa Kindergarten which involved the application of entrepreneurship activities in early childhood, including several learning components, encompassing: 1) the objectives; 2) materials; 3) educators; 4) students; and 5) strategies (Sofino, 2017). This is followed by the inculcation of entrepreneurial values, performed in a series of activities that are initiated with planning, learning, implementing and evaluating. Sani and Yunus (2018) in Malaysia showed the need to relate the results of research on teaching design or planning to one another and not to a specific subject. Furthermore, the information required is centered on the objective learning content, approaches, methods used, the imparting techniques and assessment design of the teachers' teaching and learning outcomes. These are needed to play the role of an evaluation material, which ought to be performed and added on instances where there are deficiencies.

Table 1.Entrepreneurship Value in TK Mata Najwa

\begin{tabular}{|c|c|}
\hline $\begin{array}{c}\text { Value of Entrepreneurship } \\
\text { Character }\end{array}$ & Indicator \\
\hline Hard work & $\begin{array}{c}\text { Complete the task earnestly (never give up) overcome } \\
\text { obstacles }\end{array}$ \\
\hline Honest & $\begin{array}{l}\text { A behavior that is based on efforts to become a trusted } \\
\text { person, both in words and deeds }\end{array}$ \\
\hline Discipline & $\begin{array}{l}\text { Actions that exhibit orderly behavior and comply with } \\
\text { various rules and regulations }\end{array}$ \\
\hline Creative & $\begin{array}{c}\text { To think and prepare something, or to produce a new way } \\
\text { or result from a personal item }\end{array}$ \\
\hline Independent & $\begin{array}{l}\text { Attitudes and behaviors that are not dependent on others } \\
\text { in a bid to complete tasks }\end{array}$ \\
\hline Action-oriented & $\begin{array}{c}\text { Take the initiative to act and do something without } \\
\text { waiting for an invitation from the teacher, before an } \\
\text { undesirable event occurs }\end{array}$ \\
\hline Dare to take risks & $\begin{array}{l}\text { The ability of children to enjoy challenging work is brave, } \\
\text { and the capacity to take risks based on actions }\end{array}$ \\
\hline Leadership & $\begin{array}{l}\text { An attitude that shows an openness to suggestions and } \\
\text { criticism, easy to get along, cooperate and direct others }\end{array}$ \\
\hline
\end{tabular}




\section{Implementation}

The learning process is carried out after the planning stages in school activities. It can be said that planning is actuating the entire planning in entrepreneurship - based learning programs. Entrepreneurship learning is applied in the curriculum by identifying the types of activities in schools with the propensity of realized through playing, and the related values are integrated into learning tools (Nurhafizah, 2018).

In the context of character implementation, it is necessary to pay attention to the basic principles concern with the teacher, including the implementation and integration of learning, continuity, and holism, as well as the synchronization between those taught and practiced (Suriansyah \& Aslamiah, 2015).

The learning process is often conducted by the school after the planning stages. Hence, planning is said to be the embodiment of the strategies already put in place within an entrepreneurship-based learning program. Furthermore, the implementation at Mata Najwa Kindergarten is an agreement with the study outcome of Novitawati (2016), which stated the need for two preparatory steps, encompassing: 1) The preparation of teaching, which means checking and managing everything needed in the learning process, that takes place following a plan. This includes preparing materials, media, and equipment; 2) opening the lesson, which involves praying, student absence, conveying information and motivating students. Moreover, information obtained from the findings stated that Mata Najwa Kindergarten developed the following strategy to realize the values of entrepreneurship: habituation, direction or scaffolding, the creation of learning environment, and top theme activity.

\section{Habituation}

The habits applied to tend to be effective in inculcating the values of entrepreneurship in all learning activities. This occurs because the child enters the school environment and is always accustomed to following rules or operational standards when applied based on the values of entrepreneurship. Habits in Mata Najwa are carried out by implementing the morning pledge, praying before and after eating, queuing to wash hands and take out the trashes. Refraction raises the value of discipline for children.

This practice results in developing awareness on the importance of a stipulated value, through the formation and habituation of entrepreneurial characters into children, in the learning process within and outside of the classroom. Suriansyah (2011) described it as one of the strategies adopted in an attempt to shape the character of early childhood. Moreover, the application of habituation in BIAS Palagan Yogyakarta kindergarten by Sudibyo (2015), which was based on the management of character education was prepared by schools that compulsorily integrate it into the learning activities. This routine is formed through the character habituation of classroom learning.

\section{Direction or scafflolding}

In the Centre of lesson plan there four scaffolding namely environmental scaffolding, scaffolding before playing, scaffolding in the middle of playing and scaffolding after playing. Each of scaffoldings has school's applying operational standard. According to Yuliani Nurani Sujiono (2011) the approach of implementing Early Childhood Education (PAUD) which focuses on children who are in the learning process centered at the play center and when the child is in a circle by using 4 types of scaffolding to support child development. The scaffolding is dynamic support adjusted to the development achieved by children who are given as a foothold to achieve higher development. Each action is initiated with the application of a foothold from the teacher, in an attempt for the child to understand the values of entrepreneurship from tasks performed. For example, activities in the classroom, including hand washing and ablution of children are oriented towards the action of queue and not snatch, subsequently using the water as needed. Furthermore, at the time of prayer children tend to become priests, muezzins and lead prayers, known to be a leadership value of entrepreneurs. This, therefore, explains the necessity to learn leadership and so on, performed to enhance understanding. Also, the 
practice intends to accomplish goals, and not just to run activities in school without a meaning.

The application of learning through centers in Mata Najwa Kindergarten instill entrepreneurial values, which is in line with the research conducted by Fatmawati and Latif (2019). This reported the adoption of a learning center model at Amal Insani Kindergarten that designs centers that tackle environmental scaffolding before, during and after playing. This was in line with the research by Ridho, Markhamah and Darsinah (2015), who conducted the implementation of learning in KB Cerdas Sukorejo to begin with happy morning, activities of habituation, transitions, footing environment, footing before playing, footing after playing, introduction praying and closing prayer. Learning was referring to the principle of learning while playing with the approach of beyond center and circle time (BCCT). The habituation through pledge in the morning, read the Qur'an, learning in Classroom (Regular I 7 II), nap and lunch together.

The creation of a learning environment

The setting of the learning environment in school has an influence on children's behavior and learning directly. The children's interaction, surrounding environment, learning process, productively can be created by school by the fun learning environment.

The learning environment in Mata Najwa Kindergarten is when doing class activities, the teacher makes classroom arrangements with centers and the selection of playing instruments that attract children's interests that are adapted to the child's development. Children learning environment is adapted to the child's age when outside supports the child's motoric development

According to Suhaimi (2016), the learning environment is everything related to the place where the schooling process is performed. This consists of the physical, social and cultural setting.

Learning environment at Mata Najwa Kindergarten that classroom environment with a stronger focus on instruction in conjunction with more positive affect had children who exhibited more intense engagement in learning. Rosnita, Rudiyanto and Mariyana (2016) that setting or arrangement the outdoor learning environment by paying attention to structuring adequate infrastructure so that the child's gross motor skills develop properly.

According to the Kementrian Pendidikan and Kebudayaan (2015), the guidelines for classroom management, in relation with the requirements for procurement and structuring of the learning environment, include considerations for 1) the ability for space and place used in learning to attract and invite children's interest to play; 2) everything and every area ought to contain elements of education, encompassing the aspects of color, light, plants, bathrooms, kitchens, gates, and the arrangement of play materials; 3) Characterized by safety, comfort, healthy and free from objects that possess the capacity to hurt children; and 4) emphasizing on a variety of media, including the storage of natural, waste and play materials in places that are easy to access, use and replaced by children.

\section{Top theme activity}

These include supporting activities that are connected with the main theme, which were identified on the two school sites, encompassing market day, outing class, field trips, cooking classes, parent teaching in fun cooking and conditioning activities. Furthermore, others that were specified at Mata Najwa Kindergarten include competitions, parent teaching and the observational assessments of children's work received by teachers. Besides, all of these activities were reported at the end of the semester. According to Maryatun (2017), the following were adopted in the determination of themes source themes: 1 ) Regulation based on the children's interest, conducted for the implementation to be meaningful; 2) Special events, including Independence Day commemoration, and others; 3 ) ongoing events or incidental themes that tend to be very interesting and meaningful to children.

One of the supporting activities is parent teaching occurs in the form of parent active involvement in learning within schools. The parent involvement program in learning instigates a revolution on the quality of education (Masyitoh, 2013). 
The top activity of the theme at Mata Najwa Kindergarten as types of activities capable instilling an entrepreneurial spirit in early childhood: 1) A cooking class that increases the proficiency in children's creativity towards experimenting and generating food, leading to gain in experience and new knowledge; 2) outing class characterized with efforts to provide new nuances and experiences tend to assist in optimizing the process of implant the desired knowledge; and 3) market day encompass activities that build entrepreneurship skills, alongside instill the aim, and encourage the concept of financial capability, consequently improving education for sustainable development (Krisdayanthi, 2018). Condrasky, Graham \& Kamp (2006), where it was stated that the cooking class is innovative programs in preschool children. These are usually conducted to promote healthy eating behaviors, attained by providing the knowledge on basic nutrition, food selection, menu planning, timesaving tips in the kitchen and food preparation skills to parents and caregivers. This is also significantly increased their willingness to explore fruits and vegetables, as reported by parents. Also, the effectiveness of cooking on children's food-related preferences, attitude and behaviors is promoted (Hersch et al., 2014). The strategy of implementing entrepreneurship values is similar to the report of Ulwiyah (2012), where the results and discussions stipulated that the values of entrepreneurship need to be internalized in students include independent, creativity, the dare to take risks, action-oriented, leadership, hard work, honesty, discipline, innovation, responsibility, cooperation, unyielding, realistic commitment, curiosity, communicative, and strong motivation for success. This integration is conducted in the learning process, through the role of the teacher as a designer, and the implementation is as outlined in the preparation of the syllabus and lesson plans.

Efforts to instill the value of entrepreneurship through habituation and learning in the center are in line with the report by Novitawati (2013), which stated the impact of stimulation provided by teachers towards the readiness of children at school, in aspects of development. This is attained through habituation, role models, and learning at the center, and conducted following the theme. Therefore, activities are integrated to stimulate aspects of child development and also provide opportunities through play activities.

Entrepreneurship activities performed at the peak of the theme are similar to the results of Sofini's research (2017), which was conducted in an early childhood education as an institution, encompassing cooking and outing class, as well as market day. This accomplishing is also in line with the results of implementing and monitoring conducted by Peclic and Vujatovic (2014) on projects in kindergartens. Hence, it is concluded that the execution of entrepreneurship projects possesses numerous different stimuli within the child's environment. Furthermore, children tend to have the opportunity to participate in activities where new valuable items are produced by their own hands. These activities enhance the development of an upright manner by each member in a team, as required in the conduction of teamwork. This project, further, enables participants to build stronger links with others.

\section{Evaluation}

The school's efforts in knowing the successful to grow the entrepreneurial value in the student through evaluation form the teacher. Rachmayanie (2017), assessment strategy for early childhood ought to be performed following the level of fast development, to ascertain if proper conduction. Therefore, on instances where improper evolution is identified, there is a need for the measurement and evaluation procedures to make decisions regarding appropriate service interventions, about the specific characteristics of early childhood. Furthermore, the process is conducted by taking several perceptions into account, encompassing: 1) performing the individual evaluation by comparing the current with the previous level of development, 2) take into account the differences in the development, culture, and experience, 3) not through the conduction of tests, and 4) the 
child's progress is also reported in the individual context, about performance in the age stages.

Evaluation techniques used include observation and anecdotal notes, where the teacher directly observe behaviors during the implementation of learning. This is followed by records and documentation of the activities performed by the child. Also, an instrument is used to evaluate the achievement of entrepreneurship values adjusted into the 2013 curriculum, which was the following indicators of affiliated achievements for kindergarten/early childhood education.

Reports based on the learning outcomes of Mata Najwa Kindergarten are in line with the research by Damayanti et al., (2018) which stipulated that the concept requires the combining and archiving of all data obtained. This is a collection of the results obtained from merging children's data into portfolios that are reported to parents. Furthermore, the assessment technique adopted at the Mata Najwa Kindergarten is similar to that of Furyanti (2019), stipulating the use of observation procedures in the form of checklists, conversations, assignments, performance, and work. Also, the results of this assessment were collected and poured in a report card document that contains information related to development, and achievement, as well as a checklist note.

This evaluation is in line with the research by Afifah, Suriansyah and Aslamiah (2019) this stipulated that the evaluation written in report card were performed by the homeroom teacher and parents, based on the components of development that serve as a reference, assessment, and established to enhance the proper development.

Through the evaluation of learning, children are expected to have the entrepreneur characteristics, which is attained during the education process. This is in line with the report by Sarikaya and Coșkun (2015), where it was stipulated that children within the preschool period have entrepreneur characteristics and skills. Furthermore, the provision of social entrepreneurship education was required, to ensure a considerable step is taken towards actualizing the children's future and expand the impact area of social entrepreneurship. A study by Leksono et al., (2018), refer to the implementation of early childhood education, based on the standards provided by the education office. Furthermore, the results on assessment are described and the extent to which the development process is experienced by the child is explained. Farida (2017) stated that the evaluation at was performed through 1) observations, which were conducted daily, from the child's entry to return, to obtain information on the level of development; 2) recording anecdotes of practices relating to all activities (both positive or negative) in child's development; and 3) arecorded portfolio obtained by observing their work and diary.

\section{Factors Affecting}

Every educational activity often possesses (1) inhibiting factors, which is usually faced, and need some solutions, to ensure the educational goals are attained. (2) Supporting factors also tend to be different in each institution during the management of entrepreneurship-based learning in Mata Najwa Kindergarten.

This implementation is, however, inseparable from some constraints, encompassing activity funds that are not following budget planning. The principals make an effort to overcome finances by reduce and cut down funds that are not too important in activities, and also use non-binding finances from people and parents.

The next obstacle is the educational background of teachers that do not fit in the specific field of education. Furthermore, only principals with a sound educational background make it possible for the conduction of teacher resource development activities. This is characterized by training and workshops, required to participate in seminar activities. Besides, the study background is observed to be a national challenge, as expressed by Suriansyah (2011). This stipulated the school principals' view of education and competence as anticipation of the government policies, regarding the qualifications and proficiency standards for principals and Kindergarten/Islamic Kindergarten /early 
childhood education teachers. Peklic and Vujatovic (2014) stated an educator needs a workshop, conducted in an attempt to foster familiar with the processes to be later carried out, through activities with the children.

Another obstacle is the existing infrastructure is the strive to maximize the learning activity in schools, conducted in the aspects of child development stages. Therefore, a good relationship with the community around enhances the tendency for beneficial involvement in the school. Eventually, there is a possibility of obtaining a near building, which is rented at a low price for learning activities.

There are numerous different forms, levels, and types of participation in education with the potential to provide benefits to children. Seefeldt and Barbara (2008) mentioned a collaboration between parents and schools is built on effective communication and trust. This is seen from the parent teaching activities, which serve as a supporting activity, thus parents become aware of the environment that forms behaviors with the value of entrepreneurship in children.

The conduction of these activities is following the opinion of Suriansyah and Aslamiah (2015), which stipulated the propensity to realize trust towards the educational services, with an effective partnership between the school, the community, and parents. This belief is an impact of the fact that it is seen by customers in the quality aspects of the educational service process and the institution's products. Maimunah, Aslamiah and Suriansyah (2019),

stipulated the impact of implement a family involvement program in developing student character. This is seen in the result of analyzing the changes observed in family behavior in student's habituation at home. Hence, there is a need for parental involvement programs in preschool, with the sole aim of developing student's character by regularly building positive communication between teachers, other schools and the development of relationships.

There is a possibility that the involvement of parents is the solution expected to improve the quality of learning in Mata Najwa
Kindergarten. A similar study by Irma, Nisa and Sururiyah (2019) in Purworejo, also stipulated the following positive realizations in Masyithoh 1 kindergarten through the program: 1) parenting education; 2) provision of related information; 3) home learning; 4) children's performance; 5) recreation; 6) collaboration with the community (the top theme); 7) home visits; and 8) activity participation in schools.

The supporting factors provide innovation in learning, and this was performed in both sites, which was in line with the report by Modenov, Vlasov and Markushevskaya (2018). This reported the non-consideration of entrepreneurship and innovations as activities that are limited to the impact of a sole entrepreneur, thus equal obligations ought to be met by other individual employees in larger organizations. Furthermore, the technical aspects of entrepreneurship and innovations are taken into account, as well as the nontechnical considerations, encompassing shaping an entrepreneurial climate and mentality, facilitating trials and learning, increasing adaptive abilities and the ability to learn, searching for new ways to organize the innovation process, providing a balance between the need for autonomy and corporate strategy, and also finding the right exploitationresearch combination.

\section{Conclusion and Recommendation}

In the implementation of entrepreneurship-based learning management, several strategies need to be considered starting from planning, implementation, and evaluation. planning is carried out starting from the determination of the vision and mission to the preparation of learning plans using the 2013 curriculum at TK Najwa Kindergarten. The activity involved various parties ranging from school principals, teaching teachers, to parents.

To ensure the quality of implementation as a tangible manifestation of planning, there are strategies to realize entrepreneurial values namely habituation, direction or scaffolding, the creation of a learning environment, and the main theme activities. The final stage is an evaluation carried out by making observational reports, anecdotal records, work, conversations, 
and appearances, carried out with educational principles, authentic, objective, accountable, and transparent.

In its implementation, limited funds, the quality of teacher skills and infrastructure are still the main issues that are hampering the implementation of entrepreneurial-based management in TK Najwa Kindergarten.

Based on the results of research, the following suggestions were deduced: (1) There is a need for school principals to engage the maintenance and improvement, to promote the optimal achievement of entrepreneurshipbased learning. This requires good cooperation between principals, teachers, students, and parents, as well as the managers or the head of the foundation, to foster the provision of adequate school facilities and infrastructure, which is very necessary for the proper running of learning activities; (2) For teachers, cooperation is highly needed, alongside support for entrepreneurship-based learning, which is attained with a series of guidance and training. This ought to be practiced, to apply knowledge and realize young people with an entrepreneurial mentality; (3) For further researchers, there is a need to apply subsequent related studies on other kindergartens, to input the desired values into the kindergarten curriculum.

\section{Acknowledgment}

The author is grateful to Mata Najwa Kindergarten, Banjarbaru, and with all humility thanks Ahmad Suriansyah for the mentorship, and Juhriyansyah Dalle for the helping and being a supporting author.

\section{References}

Afifah, N., Suriansyah, A., \& Aslamiah. (2019). Implementation of islamic aqeedah based curriculum at Khoiru Ummah Tahfizh Plus kindergarten. Journal of K6 Education and Management, 2(1), 47-57. Retrieved from dev.j-k6em.org

Anwar, M. (2014). Pengantar kewirausahaan (teori dan aplikasi). Jakarta: Kencana.

Asniwati. (2015). Pengembangan manajemen mutu terpadu untuk penyelenggaraan pendidikan pada sekolah dasar di kota Banjarmasin. Prosiding Seminar Nasional PS2DMP UNLAM. 1, pp. 9-16. Banjarmasin: Universitas Lambung Mangkurat. $\quad$ Retrieved from www.rumahjurnal.net/index.php/PS2DMP
Condrasky, M., Graham, K., \& Kamp, J. (2006). Cooking With Chef: An Innovative Program to Improve Mealtime Practices and Eating Behaviors of Caregivers of Preschool Children. Journal of Nutrition Education and Behavior, 38(5), 322323. doi:10.1016/j.jneb.2006.04.005

Damayanti, E., Hartika, A. S., Herawati, Lisna, Jannah, R., \& Pratiwi, S. I. (2018). Manajemen penilaian pendidikan anak usia dini pada taman kanak-kanak Citra Samata Kabupaten Gowa. Naeneke Indonesian Journal of Early Childhood Education Vol 1 (1), 13-24.

Delitasari, I., \& Nurhidayah. (2017). Implementasi pendidikan entrepreneurship di SD Entrepreneur di SD Entrepreneur Muslim Alif-A Piyungan Yogyakarta. Proceeding the Gth University Research Colloquium (URECOL) (pp. 179-186). Magelang: Universitas Muhammadiyah Magelang. Retrieved from http://journal.ummgl.ac.id/index.php/urecol/article/vie $\underline{\mathrm{w} / 1379}$

Fadillah, M. (2014). Desain pembelajaran PAUD: tinjauan teoritik \& praktik. Jogjakarta: Ar-Ruzz Media.

Farida, S. (2017). Pengelolaan pembelajaran PAUD. Jurnal Pemikiran, Penelitian Pendidikan dan Sains, 5 (2), 189-200. doi:10.31102/wacanadidaktika.5.02.189-200

Fatmawati, \& Latif, M. A. (2019). Implementasi model pembelajaran sentra di TK Amal Insani Yogyakarta. Golden Age Jurnal Ilmiah Tumbuh Kembang Anak Usia Dini, 4(2), 25-34. Retrieved from http://ejournal.uin-suka.ac.id

Furyanti, N. (2019). Penerapan pengelolaan pembelajaran di taman penitipan anak. Seminar Nasional PGPAUD UNTIRTA 2019 (pp. 251-261). Banten: Universitas Sultan Agung Tirtayasa. $\quad$ Retrieved from http://semnaspgpaud.untirta.ac.id/index/php/

Hersch, D., Perdue, L., Ambroz, T., \& Boucher, J. L. (2014). The impact of cooking classes on food-related preferences, attitudes, and behaviors of school-aged children: a systematic review of the evidence, 2003-2014. Journal of Preneting Chronic Disease: Public Health Research, Practice, and Policy, 1-10. doi:10.5888/pcd11.140267

Irma, C. N., Nisa, K., \& Sururiyah, S. K. (2019). Keterlibatan orang tua dalam pendidikan anak usia dini di TK Masyithoh 1 Purworejo. Jurnal Pendidikan Anak Usia Dini, 3(1), 214224. doi:10.31004/obsesi.v3i1.52

Ita, E. (2018). Manajemen pembelajaran pendidikan anak usia dini di TK Rutosoro Kecamatan Golewa Kabupaten Ngada Flores Nusa Tenggara TImur. Jurnal Dimensi Pendidikan dan Pembelajaran, 6(1), 44-52. doi:10.24269/dpp.v6i1.889

Kementerian Pendidikan dan Kebudayaan. (2015). Pedoman perencanaan pengelolaan kelas pendidikan anak usia dini. Jakarta: Kementrian Pendidikan dan Kebudayaan. 
Krisdayanthi, A. (2018). Menumbuhkan jiwa kewirausahaan pada AUD sebagai bekal kecakapan hidup. Jurnal Pratama WIdya, 3(2), 20-27. doi:10.25078/pw.v3i2.734

Leksono, F. D., Sulton, \& Susilaningsih. (2018). Implementasi kurikulum 2013 PAUD di TK TPI Nurul Huda Malang. Jurnal Jinotep, 4(2), 126-131. doi:10.17977/um031

Maimunah, Aslamiah, \& Suriansyah, A. (2018). The integration of sentra-based Learning and involvement of family program at early childhood in developing character building (Multi Case at PAUD Mawaddah and PAUD Alam Berbasis Karakter Sayang Ibu Banjarmasin, Indonesia). European Journal of Education Studies, 49-63. doi:10.5281/zenodo.1494207

Maryatun, I. B. (2017). Pengembangan tema pembelajaran untuk Taman Kanak-Kanak. Jurnal Pendidikan Anak, 6(1), 41-47. doi:10.21831/jpa.v6i1.15679

Masyitoh, S. (2013). Penerapan program pelibatan orang tua siswa dalam pembelajaran: studi kasus terhadap program guru tamu di TK Global Cendikia School Kelurahan Babakan Sari kecamatan Kiaracondang Kota Bandung Tahun Ajaran 2011-2012. Bandung: Universitas Pendidikan Indonesia (Thesis tidak diterbitkan). Retrieved from http://repository.upi.edu/id/print/2401

Modenov, A. K., Vlasov, M. P., \& Markushevskaya, L. P. (2018). Innovative aspects of entrepreneurship education: preparing a new generation of entrepreneurs. Journal of Entrepreneurship Education, 21(Special Issue), 1-7. Retrieved from https://www.abacademies.org/articles

Musfah, J. (2012). Pendidikan holistik: pendekatan lintas perspektif. Jakarta: Kencana.

Ningrum, M. A. (2017). Peran keluarga dalam menumbuhkan jiwa wirausaha sejak usia dini. Jurnal Pendidikan, 2(1), 2932. doi:10.26740/jp.v2n1.p39-43

Novitawati. (2013). Kesiapan sekolah anak taman kanak-kanak berbasis model pembelajaran sentra (studi kualitatif di Taman Kanak-Kanak Islam Sabilal Muhtadin Banjarmasin, Tahun 2011). Jurnal Pendidikan Anak Usia Dini, 7(1), 109132. Retrieved from www.neliti.com/publications/118204

Novitawati. (2016). Peran manajemen partisipasi orang tua dalam manajemen pembelajaran di Taman Kanak-Kanak sebagai upaya optimalisasi perkembangan anak usia dini. Prosiding Seminar Nasional PS2DMP UNLAM. 2, pp. 31-36. Banjarmasin: Universitas Lambung Mangkurat.

Nurhafizah. (2018). Bimbingan awal kewirausahaan pada anak usia dini. Jurnal Konseling dan Kependidikan, 6(2), 62-66. doi:10.29210/127300

Nurseto, T. (2010). Pendidikan berbasis entrepreuner. Jurnal Pendidikan Akuntansi Indonesia, 8(2), 52-59. doi:10.21831/jpai.v8i2.954
Peklić, J., \& Vujatović, D. (2014). Education entrepreneurship in kindergarten. Journal of HRČAK, 4(1), 89-96. Retrieved from https://hrcak.srce.hr/134606

Prawirokusumo, S. (2010). Kewirausahaan dan manajemen usaha kecil. Jogjakarta: BFEE.

Rachmayanie, R. (2017). Penggunaan asesmen portofolio pada pembelajaran anak usia dini. Konferensi Tulisan Ilmiah Himpunan Evaluasi Pendidikan Indonesia (pp. 418-425). Banjarmasin: Penguatan Literasi Guru Dalam Asesmen Kelas. Retrieved from http://eprints.ulm.ac.id/6533/

Ridho, R., Markhamah, \& Darsinah. (2015). Pengelolaan pembelajaran pendidikan anak usia (PAUD) di KB "Cerdas" Kecamatan Sukerejo Kabupaten Kendal. Jurnal Penelitian Humaniora, 16(2), 59-69. doi:10.23917/humaniora.v16i2.1857

Rosnita, A., Rudiyanto, \& Mariyana, R. (2016). Hubungan antara penataan lingkungan belajar outdoor dengan kemampuan motorik kasar anak usia dini. Edukids Jurnal Pertumbuhan, Perkembangan dan Pendidikan Anak Usia Dini, 14(1), 218$229 . \quad$ Retrieved from http://ejournal.upi.edu/index.php/edukid/article/view/ $\underline{17090}$

Sani, N. A., \& Yunus, F. (2018). Amalan perancangan, pelaksanaan, dan pentaksiran dalam proses pengajaran dan pembelajaran pranumerasi di Tadika Swasta. Jurnal Pendidikan Malaysia, 43(2), 101-110. doi:10.17576/JPEN2018-43.02-10

Sarikaya, M., \& Coṣkun, E. (2015). A new approach in preschool education. Procedia Journal of Social and Behavioral Sciences 195, 888-894. doi:10.1016/j.sbspro.2015.06.368

Seefeldt, C., \& Wasik, B. A. (2008). Pendidikan anak usia dini menyiapkan anak usia tiga, empat dan lima tahun masuk sekolah. Jakarta: Indeks.

Siwiyanti, L. (2016). Building the character of entrepreneurship for pre-school student through science. Seminar Nasional Pendidikan Berkemajuan dan Menggembirakan (Progessive \& Fun Education Seminar) (pp. 377-382). Solo: Muhammadiyah University Press. Retrieved from http://hdl.handle.net/11617/7669

Sofini. (2017). Pembelajaran kewirausahaan. Prosiding Seminar Nasional Pendidikan "Optimalisasi Peningkatan Mutu \& Kemandirian Dalam Menciptakan Lapangan Kerja Lulusan Prodi PNF Menghadapi Mea dan Bonus Demographi 2045". 1 (1), pp. 61-69. Bengkulu: Unit Penerbitan FKIP Universitas Bengkulu. Retrieved from http://repository.unib.ac.id/id/eprint/11764

Sudibyo, P. (2015). Manajemen pendidikan karakter di Taman Kanak-Kanak BIAS Palagan Yogyakarta. Jurnal eL-Tarbawi, 8(2), 195-206. doi:10.20885/tarbawi.vol8.iss2.art6 
R Firdausi, KI Ahmad, R Rachmayanie, 2019 / Implementation of entrepreneurship-based learning management

Suhaimi. (2016). Menciptakan lingkungan belajar yang aman untuk proses belajar mengajar. Prosiding Seminar Nasional PS2DMP UNLAM. 2, pp. 57-52. Banjarmasin: Universitas Lambung Mangkurat. 